\title{
Critical Discourse Analysis of Tariq Ali's Novel "The Stone Woman”: A Corpus Driven Study
}

\author{
M. Asaf Amir ${ }^{1} \&$ Asim Mehmood ${ }^{1}$ \\ ${ }^{1}$ Govt.College University Faislabad, Pakistan \\ Correspondence: M. Asaf Amir, Govt.College University Faislabad, Pakistan. E-mail: \\ masafamirmalik@gmail.com
}

Received: June 26, 2017

Accepted: September 27, 2017 Online Published: October 25, 2017

doi:10.5539/ijel.v8n1p94

URL: https://doi.org/10.5539/ijel.v8n1p94

\begin{abstract}
The purpose of this paper is to explore the ideology working behind Tariq Ali's novel The Stone Woman through Critical Discourse Analysis (CDA) by applying corpus driven approach. Gee's (2011) CDA tools have been used to explore the ideology working behind the novel. This ideology has been subjected to Althusser's (1969) theory of ideology to find how Ideological State Apparatus (ISA) collaborates with Repressive State Apparatus (RSA) to naturalize and internalize certain ideologies. It has been concluded that the supremacy of the male members of the family and society has been accepted as an ideology and this ideology has been naturalized and internalized by using certain institutions like marriage, family, customs and traditions. Not only the ideologies have been institutionalized but also this process works for the extension, strength and dominance of the male members of the society.
\end{abstract}

Keywords: Stone Woman, ideology, male, dominance

\section{Introduction}

This paper is the critical discourse analysis of Tariq Ali's novel The Stone Woman. The aim of study is to explore the ideology working behind the narrative of Tariq Ali. The focus of the present study is the gender discrimination which is the pop up feature as we analyze the corpus of the narrative. The male chauvinism is at the peak in that society and this dominance of the male members of the society leads to the deprivation of the rights of the female members of the society. Moreover, this exploitation of the male members has been institutionalized. (Fairclough, 2010) The institutions like marriage, family and traditions have been used for curbing and subjugating women. The process of oppression of women is carried out so implicitly that nothing seems unnatural and out of the way to us.

The phenomena of gender discrimination and the subjugation of women is not something new. However, it came to the forefront with the movement of the emancipation of women in 1970s.Feminism has been the most influential political and social movement that has affected the field of social research. The feminists do not believe that women are naturally inferior to men. What is distinctive about feminism is the particular political positioning of theory, epistemology and ethics that enables the feminist researcher to question existing truths and explore the relationship between knowledge and power (Ramazanğolu \& Holland, 2002). Feminist inquiry asks "How is this [the feminist] perspective manifest in this phenomenon?" (Patton,2002). The present study explores how the exploitation of women by the dominant class of men works as an ideology and how this ideology is naturalized and internalized through different institutions. The process of exploration has been done by analyzing the narrative of Tariq Ali's novel "The Stone Woman" through CDA.

The relationship of feminism with CDA is of complementary nature. Terry (2014) is of the view that feminist CDA is helpful in bringing about the social change that is useful on material and phenomenological basis for men and women living in different communities. The aim of feminist CDA is therefore "to show up the complex, subtle, and sometimes not so subtle, ways in which frequently taken-for-granted gendered assumptions and hegemonic power relations are discursively produced, sustained, negotiated, and challenged in different contexts and communities." (Lazar, 2010). This study does not specifically deal with feminist CDA but as the narrative of "The Stone Woman" displays pop up features of feminism so it is worthwhile and pertinent to mention the relationship of feminism with CDA. 
A suitable methodology that may serve the purpose of the research that is to explore the ideology working behind the novel is the synergization of CDA and Corpus linguistics (CL). An ample insight in the area of CDA is provided by Fairclough (1993, 1995, 2000, 2001, 2004, 2006, 2010), Halliday (1985, 1996), Myers (2008), Sinclair (1991), Leeuwen (2009), Wodak (2009), and Dijk (1981, 1984, 1988, 1991, 1998, 2008). Some of the limitations that the traditional qualitative CDA approach has and are pointed out by the above mentioned body of knowledge are:

i. Unrepresentativeness ii. Comparability and iii. Subjectivity.

In order to come over these limitations, an approach is needed that could limit the limitations of CDA. The use of technology in the field of language is not a new phenomenon. It has been experimented in the area of CDA by Fowler \& Kress (1979), Simpson (1993), Van Dijk (1988), Stubbs (1994), Flowerdew (1979), Koller (2005), Baker (2006), Mautner (2006), Krishnamurthy (2010), MecEnery (2012). There has already been a lot of research work by using the amalgam of the two methodologies. Finally, CL to combine with CDA has been chosen as methodology for the present study.

This choice solved the problem to some extent as CL is helpful in minimizing the limitations of the CDA pointed above but CL has its own limitations. The foremost and significant limitation is the issue of context when we synergize CL with CDA. The researchers who have used the same synergization (CDA+CL) (Baker, 2008) suggest that the issue of context can be minimized as the researcher comes across so many patterns of different lexical items during the exploration of the corpus.

As a 1st phase of the present study, nouns, pronouns and adjectives, verbs attached with these two parts of speech have been analyzed by using computer software. The patterns generating some kind of ideology relevant to the research questions have been noted. As the 2 nd phase of the present study i.e. to dig out the ideology in the discourse, four tools from Gee (2011) have been used. The application of these tools on the collected data leads us to the implicit ideology working behind Tariq Ali's novel. The tools are:

i- Context as a reflexive tool: ii-The Fill in Tool: iii-Why This Way and Not That Way Tool: iv-The big "D" Discourse Tool:

Now the 3rd phase of this study starts. For this purpose, Althusser's theory of Ideology (1969) has been used to dissect the ideology present in the narration. Althusser's theory of Ideology dissects the ideologies into Repressive State Apparatus (RSA) \& Ideological State Apparatus (ISA). To sum up the introduction of methodology, it moves forward in three steps: from CL to CDA \& Althusser's theory of ideology.

\subsection{Relevant Scholarship in $C D A$ and $C D A$ Using $C L$}

Fairclough's work is comprehensive and has the status of a school of thought in itself. He has described three properties of CDA: relational, dialectical, and transdisciplinary. He calls it relational because it basically deals with social relation and not entities or individuals. Now, social relations are not linear or simple. These are very complex and have many layers. Discourse cannot be defined independently. Discourse gives meaning to the complex relations. Dialectical relations are between objects which are different from one another but still overlap. For example discourse has relation with ideology, ideology has relations with power and discourse has relations with power. As in discourse analysis of dialectical relation is not bound to single discipline but it is the to and fro across different discipline so it is interdisciplinary (Fairclough, 2001).

Van Lauwen (1996) supports Fairclough by adding that there could be two kinds of relationship between discourse and social practices; discourse itself (as) social practice, discourse as a form of action, as something people to do, or for, or with each other. And there is discourse in the Foucaultian sense, discourse as a way of representing social practice(s), as a form of knowledge, as a way of representing social practices (1993a, p. 193).

In the present study, all the three properties of CDA have been explored and utilized. The novel of Tariq Ali gives us pictures of society, the social relationship among the individuals of society.

Wodak (2001) is of the view that three forms of social representations are necessary to understand discourse:

1: Knowledge (persona, group, culture) 2: Attitudes. 3: Ideologies: Discourses take place within society and can only be understood in the interplay of social situation, action, actor and societal structures.

Stubbs (1994) works on computer assisted discourse analysis of language and culture. He develops a relationship between texts, texts types, text corpora and social institutions. His focus is on lexical and grammatical patterns in texts. He takes texts as micro structures and social institutions as macrostructures for the analysis of discourse.

This study moves a step further and from the patterns of lexical items revealed through the assistance of computer, an ideology working behind the novel of Tariq Ali has been explored. 
Flowerdew (1997) focuses research on academic discourses. He studies political identity through CDA in historiography (2012). CDA is a useful approach to study the political and religious identities formed in the texts. Some identities are formed in such a way that they look superior to others.

Magalhaes (2000) studies gender relations, the relationship of advertisement in creating the identities of both the genders. Also, he notes down the position of genders established by the producers of the advertisement. This study has also a special interest in dealing with the gender discrimination in society that forms the background of the novel of Tariq Ali. The study explores how this discrimination is ideologically naturalized.

D'Halloran \& Coffin (2004) did a useful research work by using the tool of APPRAISAL from the systemic functional linguistics (Martin, 1997, 2000; White, 2003). They use this tool for the research of how the discourses position the readers in order to create a certain mindset of the readers. It also suggests that how the computer technology of a concordance can keep to reduce an analyst's subjective intrusion. They applied functional and Corpus approaches to English grammar to check over interpretation and under interpretation.

CDA is objected for the subjectivity of the analyst. This study is using corpus driven approach to minimize the analyst's subjective intrusion. The element of subjectivity mars the quality of analysis.

Orpin (2005) observes the relationship between language and ideology. He uses Corpus methodology to generalize the result reliably. He also studies islomophobia, representation of Chinese dreams on media, analysis of corruption in presidential speeches. There is a close relationship between language and ideology and the object of the present study is to explore this relationship.

Koller (2005) studies the relationship between CDA and cognitive linguistics. Her focus is on metaphor research. She argues that metaphoric models play an important role in the construction of an ideology and vice-a-versa. Metaphors are used as careers of ideology to attract attention, implant conviction and desire to buy the products. Her work on identity, gender, color, cognition, racism is a land mark in the field of CDA.

Baker (2006) wrote a seminal book, "Using Corpora in Discourse Analysis". This book gives us different techniques of the analysis of language for a particular purpose. It informs about the use of corpora in order to uncover linguistic patterns which enables us to understand how language is being used to construct different discourses. It discusses holiday brochures, parliament debates, and newspaper reports etc. as examples to combine the quantitative and qualitative approaches of CDA. It discusses the techniques of collecting the data from the corpus to be utilized for CDA. Baker's work is commendable as it suggests the ways for the future researchers to work in this area.

Mautner (2006) did a lot of work on the methodology concerning corpus and CDA. She tries to combine the traditional qualitative approach of CDA with CL. Mautner is in favor of using concordance programmes for better analysis of discourse and the present study has also been using the same methodology. Mautner uses web-based corpora in CDA.

Krishnamurthy (2010) studies CDA, using corpora on number of topics. It used corpora for studying collocations, ethnic, racial and tribal discourse, the discourse of climate change, language change in Young Punjabi/ English children. The discourse of climate change is a hot discourse of today. Krishnamurthy, through the discourse analysis of media reports about climate change shows that there are certain countries paying noticeable importance to this problem while others are less attentive to it

\subsubsection{CDA of Tariq Ali's fiction}

Gamal (2011) attempts to discover the rewriting strategies in Tariq Ali's postcolonial metafiction. He argues that writing and rewriting are compulsorily attached to each other and the post-colonial writers are rewriting their history as a form of "culturally canonical texts." According to him, "Tariq Ali has thus developed his own brand of postcolonialism, an option inspired by the need to present possible alternative realities of Third World history". (p. 16)

All the postcolonial writers are trying to rewrite the history of the colonial period. Tariq Ali has also rewritten the history of the colonized areas and naturally he has invested his writings with an ideology. The present study is an effort to explore that ideology.

Wikander (2013) examines the Shadows of the Pomegranate Tree as an effort to subvert Eurocentric notions on history and culture. According to the study Shadows of the Pomegranate Tree focuses on the "non Eurocentric Portrayal of history and Islamic culture."

Hassan (2014) views Tariq Ali's novel Shadows of the Pomegranate Tree from deconstructionist angle. According to this study, novel is a counter narrative against the west's orientalist view of the Muslim culture and 
history. Also, the text of the novel deconstructs its own ideological agenda by not focusing upon the intellectual aspect of the Muslims and paying more attention to the erotic and sensual aspect of the Muslims.

Ali (2014) claims that Tariq Ali's Islam Quintet presents the secular side of Islam. It highlights that the Muslims were tolerant, pluralistic as well as intellectuals. It is the process of retelling the history from the other's perspective.

The present study is the CDA of Tariq Ali's novel "The Stone Woman" by using Corpus driven approach. The synergy of the two different approaches i.e., CDA \& CL for the present study is a novel experiment concerning the Pakistani fiction. There is but a little research study of Pakistani fiction from the CDA point of view. This study will fill that gap. The researchers like Mehmmod \& Mehmood (2009), Ahmad \& Ali (2015) presented their studies from the angle of proving the Pakistan English as a separate variety or an effort has been made to study the style of Pakistani fiction writers. The present study will open new vistas of research about the other authors of Pakistani fiction. There are large numbers of CDA studies covering the fiction world over. Through corpus driven CDA, all these studies can be re-analyzed and re-confirmed.

\subsubsection{Research Questions}

This study is interested to find the answers of the following research questions.

1) What is the ideology working behind Tariq Ali's novel "The Stone Woman"?

2) How the ideology of the dominance of man has been naturalized and internalized?

3) How do certain discourses are made superior and legitimized?

\section{Methods}

A computer software antconc 3.2.4 has been used to analyze nouns, pronouns and adjectives, verbs used with these two parts of speech. The analysis consists of three steps which have been applied simultaneously to explore the ideology working behind Tariq Ali's novel.

1) Through the study of these nouns and pronouns and attached adjective and verbs, we identify the patterns generated by these parts of speech.

2) On these patterns, the four tools of Gee (2011) have been applied simultaneously. These four tools are context based tools and provide the necessary context required for CDA. By the application of these four tools the ideology working behind the patterns of lexical items has been explored.

3) The explored ideology has been subjected to Althusser's theory of ideology (1969). This practice gives us the difference between Repressive state apparatus (RSA) and Ideological state apparatus (ISA). It shows how people are subjected to and work under different ideologies, how certain ideologies are internalized and naturalized to look normal and finally how ISA and RSA collaborate in the process of internalization and naturalization of certain ideologies

\section{Analysis \& Discussion}

\subsection{The Stone Woman}

This section consists of the Analysis and Discussion of the novel "The Stone Woman". The stone woman is a statue near the house of ruling family of Iskander Pasha. The women of the family cannot share their sufferings, sorrows and problems with anyone because of conservative family set up. These women visit the statue of stone woman to disgorge their pent-up emotions. Even some men do the same practice to relieve themselves.

\subsubsection{Nouns}

The analysis of the nouns suggests that the ideology of the dominance of male characters and deprivation of female characters is the pop up pattern of narrative and different institutions like marriage, family, customs and traditions have been used to naturalize this ideology of male chauvinism.

\subsubsection{Nouns Suggesting Male Chauvinism}

The nouns suggesting male chauvinism can be further divided into two sub-categories; the oppressors and the oppressed. The characters of women fall into the sub-category of the oppressed. The characters of male fall into the sub-category of the oppressors. The following table 1 shows the divisions of nouns into the sub-categories of the oppressed, the oppressors. 
Table 1. The oppressed and the oppressors

\begin{tabular}{ll}
\hline The Oppressed & The Oppressors \\
\hline Woman & Sultan \\
Stone Woman & Iskander Pasha \\
Nilofer & Grand Father \\
& Mehmet Pasha \\
& Man \\
\hline
\end{tabular}

\section{(A) The Oppressed}

The number within brackets against each noun indicates its frequency and $\mathrm{H}$ indicates the number of hit location from the corpus.

Woman (156)

The concordance of woman is 156 and out of these 100 are those with the adjective "stone" which is very natural as the title of the novel suggests. (The noun stone woman has been discussed separately) It is interesting to note that the remaining 56 hits are described with very interesting adjectives. For example

Table 2. Negative adjectives used with woman

\begin{tabular}{ll}
\hline Serving woman & 1 \\
\hline Old woman & 4 \\
Lost woman & 1 \\
Ugly woman & 1 \\
Peasant woman & 1 \\
Contradictory woman & 1 \\
Crazy woman & 1 \\
Evil woman & 1 \\
\hline
\end{tabular}

Out of 56 concordances, the noun woman has been qualified for 25 times, 11 are derogatory qualifiers as it has been shown by the above table 2 . Serving woman is being used for maid-servant and peasant woman in the sense of a lower class woman. There are a few $+\mathrm{VE}$ adjectives like young (3), striking (2) etc and others are neutral like French, Egyptian etc. It means that women have been depicted most of the time as black, negative side of the sexual divide. Men have the authority in the sense that they use to control the indoor as well as outdoor activities. (Gee, 2011) The family as an institution is acting like RSA used by men acting as ISA (Althusser, 1969). The structure of the family is helping man to assert his authority. The ideology of the superiority of man has been naturalized and the language is the clear manifestation of this practice. (Wodak, 2010)

Some derogatory remarks; such as "to feel sorry for the man with the woman voice." (H-106) show the status of women in that society. An ideology has been naturalized that a man's voice is always heavy \& authoritative. (Wodak, 2010)

On my head the burden of being a woman. (H-48). This is from the speech of a woman (Nilofer). She thinks that to be a woman is like a burden to her. This bespeaks explicitly about the low status of woman in that society.

To sum up, when woman is qualified with one or the other adjective, most of these adjectives are negative. There are some ideologies attached with the woman and have been naturalized. Within the family \& society, man represents ISA and he works, naturalizes and hegemonies through tradition, customs which represent RSA. (Althusser, 1969) Marriage is also an institution to keep the hegemony of the man intact. (Fairclough, 2010)

Stone Woman (100):

Stone woman is symbolic of the fact that in Pasha family women are not allowed to speak about their wishes, aims \& expectations. The institution of family is acting as RSA. (Althusser, 1969) The traditions, the male chauvinism are used to subdue the powerless women.

1) We could never agree on her identity so she became stone woman. (H-2)

It shows fluid identity of woman. She becomes a stone woman because she has no identity, she cannot live her life according to her own will, and she remains dependant throughout her life. (Gee, 2011) This is the story of most of the women of our society. They have to live their lives as per the programme chalked out by men for them 


\section{2). Stone woman became repository of all our hidden pain. (H-3)}

The eastern societies are mostly oral. Especially the women who have been deprived of their rights depend upon the mutual oral sharing of their grieves and deprivation. It creates a relationship of "sisterhood" among them. As the women do not find any male partner (Father, Brother, Husband) to share their feelings so they naturally search some one of their own sex to share their emotions. (Gee, 2011) Again, family acts as RSA in the hands of male members (ISA). (Althusser, 1969) The sentences like:

1) I missed you stone woman. (H-7)

2) "I will jump into the sky and I will fly away, stone woman." (H-20)

create a pattern which again testifies that the stone woman is treated like a living partner, sharing and caring. She is an entity to whom the women of the family could disgorge their secrets.

There are some depressed men in the same society who find no one to express themselves; they also express themselves before the stone woman. So, the stone woman is not only a repository for women but also for men.

1) "Am I really the first man to appear before you, stone woman? (H-46)

2) "I am tormented, stone woman." (H-47)

This shows that the family as RSA possesses so strict a structure that in the family of Pashas, no one could dare talk to one another. There is a kind of artificial wall around all the members of the family that does not allow them to share their feelings. They have got only one source where they could express their feelings that was the stone woman.

Out of 100, in 33 hits the stone woman has been addressed as listener (living being) as if some kind of dialogue (monologue) is going on between persons. It is one third of the total frequency of stone woman. It is a recurring pattern in the narrative.

The stone woman is addressed as "You stone woman". As 2nd person pronoun or you-attitude makes the narration to give impression that two people are very intimate, understanding level is very high and both the speakers \& the listeners are at the same level.

From stone woman, another pattern that is noteworthy is of asking question. The style of inquiry is of such nature as if the speaker wants to confirm whether his/her stance is true or false most of the time he/she takes his/her stance as true. (Gee, 2011)

1) What should one tell the children these days, Stone woman? (H-10)

2) What it is with the boys in this family, stone woman? (H-11)

Nilofer (98):

Nilofer is the central figure (heroine) of the narrative. She belongs to the ruling Pasha family. The narrative mainly consists of her memories. It is quite interesting to note that Nilofer acts as an agent in six sentences of active voice; four times she appears in passive voice and for rest of the space she has been given, she is described by others in most of the time or is addressed by her name in the direct speech within the inverted commas. Given the structure of Pasha Family, women are ignored and discriminated so Nilofer, although a very active female member of Pasha Family (married against the will of his father, had illicit relation with the son of barber who was thought to be a family barber) yet she is shown passive most of the time. She does not act as agent and is described by others. It means that even on syntactic and semantic level above the lexical level, this fact is supportive of the point that women are ignored and most of the time male members of family (ISA) work with the help of family traditions, customs, marriage and institution (RSA) to maintain their hegemony. (Althusser , 1969) Although resistance is shown by woman as individuals like Nilofer by marrying against the will of her family and then she protests against the customs by having illicit relationship with Selim (son of barber). (Gee, 2011)

Examples of the above discussion are given below:

1) ...............Nilofer writes a farewell letter to her Greek husband. (H-4 )

2) Eminah arrives at the house,Nilofer is enchanted by Iskander Pasha...(H-29)

3) Nilofer is overcome by longing for Selim.........................(H-1)

4) “And now you're a mother, Nilofer." (H-2) 


\subsubsection{The Oppressors}

\section{Sultan (114):}

Sultan is the title of the Muslim rulers in Turkey in those days. The noun "Sultan" is being used as an agent most of the time. For example;

1) As was his wont, the Sultan sent for Yusuf Pasha in the evening. (H-4)

When it is used as object in passive sentences, still it gives the impression of the agent, the controller of the action. For example

1) .....Yusuf Pasha had been disgraced and sent into exile by the Sultan in Istanbul. (H-1)

2) That was the only concession he made to the conditions imposed on him by the Sultan. (H-2)

The use of Apostrophe with Sultan shows that everything is in the possession of Sultan.

1) ......But the sight of the Sultan's face interrupted his flow. (H-12)

2) They spoke how Yusuf Pasha had fallen in love with Sultan's favourite white slave

Table 3. 'Sultan' as object, subject and apostrophe with 'Sultan'

\begin{tabular}{ll}
\hline Sultan as object in Passive voice & 3 \\
\hline Sultan as subject in Active voice & 23 \\
Apostrophe with Sultan & 9 \\
\hline
\end{tabular}

To sum up, the analysis shows that the Sultan is a very powerful ruler enjoying full authority. The ideologies are naturalized through power and language plays an important role in the naturalization of ideologies. The Sultan as an institution is a part of ISA and uses its authority (RSA) to maintain the status quo. (Althusser, 1969)

Iskander Pasha (I.P.) (177)

Iskander has very large concordance hits as compared to the other nouns. It establishes the fact that the story of the novel revolves around this central character and the author has given time as well as space to the main character. Being in authority, Iskander Pasha has been used as an agent most of the time, as an active subject. Also the verbs being used with this noun are action verbs which indicate the active state of the agent.

1). Iskander Pasha doubted his younger son's motives. (H-3)

2). Iskander pasha began to recover. (H-5)

Let us look at the clusters of Iskander Pasha's:

These kinds of clusters show the authority and possessive power of Iskander. The frequency of apostrophe with Iskander Pasha is 20.

For example, Iskander Pasha's children, Iskander Pasha's hair, Iskander Pasha's hands, Iskander Pasha's coachman, Iskander Pasha's instructions etc,

The relatives \& near \& dear ones of Iskander Pasha have been described through him.

For example

1) Iskander Pasha's children has left the house together......

2) In the time of Iskander Pasha's grandfather, there were.

Iskander Pasha is a member of ISA and he has used RSA (marriage, family, authority) to maintain status quo. (Althusser, 1969)

1) Iskander Pasha was known throughout his family for his antisocial habits and bad temper. (H-6)

2) Iskander pasha could not contain his rage, all I remember is his predatory profile as he clenched his fist and hit Salman on his face. (H-11)

Mahmut Pasha (28)

The lexis along with Mahmut shows that he is also vain, authoritative, morally weak male member of Pasha Family. He wants to reinvent the history of his family by destroying the earlier one.

1) Some say that our grandfather Mahmut Pasha destroyed the slim bound volume because 
2) Mahmut Pasha did manage to produce a book which still sits in the library unread and unloved

3) Mahmut Pasha manufactured untruths because he intended to marry a niece of Sultan

4) After all, despite Mahmut Pasha's well known habit of embroidering the truth

5) Mahmut Pasha, self loving and pleasure seeking as ever enraged by these slurs on his manhood ...

On the cluster level, we have the above examples to show that like other male members of Pasha Family, Mahmut Pasha is an addition toeing the footsteps of other male members of the family. Additionally, he has the habit of telling the lies.

That he was morally corrupt and weak but this corruption was justified because of the fact that he belonged to the ruling family is clear from the following examples.

1) They say she made Mahmut Pasha laugh a great deal and, most important ... (H-10)

2) Mahmut Pasha Circassian disappeared with the unborn child. (H-14)

3) I am eight months pregnant with Mahmut Pasha's child ...... (H-16)

Again the ruling family and the men in authority act as ISA and use their authority as well as family status as RSA to make something unnatural and morally wicked to appear natural. The ideology that the ruling class has the right over the fate and future of lower classes especially over the fate and future of the women of the ruled to do whatever they wish has been naturalized. (Wodak, 2011) No one objects over it in that society against this inhuman treatment by the ruling class.

Man (113)

The noun "man" has been qualified most of the time by the qualifiers like old (25), young (10), the (9) a (11), another (8) etc. What is interesting in the study is that there are only a few examples out of so many where "man" has been qualified negatively like dying, poor, condemned, cruel, needful etc. On all the other occasions, man has been qualified positively. Even "old man" when observed against the context, gives very healthy and positive expression. (Gee, 2011) The other qualifiers are rich, decent, nice, fortunate etc.

It shows that the society was man-dominant. Man (ISA) is using family, its traditions, (RSA) to naturalize his dominance and authority. Even some institutions like marriage are acting as RSA to naturalize the ideology of the superiority of man in the society. (Althusser, 1969) The choice of lexis indicates the same fact.

\subsubsection{Pronoun}

He (1402)

The third person singular pronoun "he" is being used for the creation of the identity of the "other" male character. (Gee, 2011) The examples can be found from clusters.

1) He was a Greek was bad enough. (H-1)

2) He was almost thirty. (H-12)

3) He was as handsome as ever

4) He was clean shaven and dressed in western clothes

There is the use of so many action verbs with the pronoun "he" regardless of the fact which male character is being described with the 3rd person singular pronoun "he".

1) Perhaps he was suffering from severe indigestion. (H-10)

2) ....... In exactly the same way as he had done for the last years

3) He had grown up with the Sultan. (H-6)

Even on the sentence level the depiction of male character represented by "he" has been glorified and has been delineated as somebody superior.

1) He was such an accomplished courtier. (H-29)

2) He was so quick witted that he could invent and recite a quatrain on the spot. (H-30)

3 He was a creature of his time. (H-60)

4) He had always been a demanding man. (H-68)

These are the examples out of total 15 clusters where again "he" has been glorified. 
In Toto, "he" has been identified as physically "handsome", "powerful". His identity has been created as an active member of society, all assertive and authoritative. He is a man of action, successful who could do daring jobs. He has every right to command the women. Now, as this is in accordance to the society of the time as "male" has every right to rule and women are supposed to be obedient and submissive. They are subjugated through the institutions like "maid servant", 'marriage' and even 'family' some time act as RSA to enslave them on the other hand "male" act as ISA and uses the institutions (RSA) of family. (Althusser, 1969) Marriage, master-servant relations are utilized to tame the women. And all these ideologies "superiority of man to woman" are naturalized to such an extent in that society that nothing seems abnormal. (Wodak, 2010)

She (547)

"She" does not appear to have identity. There is no mention of age, feelings, state of mind from which we can guess about the identity of "she". If we take "she" regardless of the fact for which character it is being used, we form an idea of a fluid, blurred kind of identity.

1) She would not have minded at all if Dmitri had belonged to one of the phanariot families of old Constantinople. (H-1)

It means "women" are careless even foolish in the choice of their life partner

2) She was never bothered about family trees. (H-2

Again, it is carelessness of women for whom belonging to respectful family does not matter.

3) It was simply that she had another sailor in mind. (H-3)

4) She had wanted me to marry her uncle's son. (H-4)

The above two examples show that the narrator wants to show that the only job of women is getting married. They do not need any identity like male members of the society.

5) Sultan and she in due course, gave birth to our father and his three sisters. (H-25)

6) She had a fair skin, luscious lips

7) ....... She possessed a body that was an embarrassment of riches. (H-29)

There is no conscious effort on the part of the author to give identity to woman. Instead, she is being described through her physique i.e. beauty of the different parts of her body.

There is no specific identity for woman. Even the analysis of first 25 concordance hits, we find that if woman has any identity which can be guessed through her feelings, state of mind, it is a lamenting, surprised, disagreeable, failed kind of personality.

Most of the verbs used with "she" are not the action verbs but "she" seems a passive spectator of the drama of life.

1) She had wanted me to marry her uncle's Sifrah's older son. (H2)

2) That the cousin for whom she intended me was not interested ..... (H-3)

3) She had shown me the delights of Kionye. (H-4)

4) Even as an eight year old she observed man in their caps. (H-9)

5) She, who boasted of how she had warmed the bed of Mahmut Pasha, (H-12)

These five are the examples of first ten concordance hits. It is enough to show that "she" is a passive character and a tool in the hands of male character or something to facilitate their lives (male).

"She" has not been glorified because of her achievements. The above examples are a case in point.

The above examples again show that there was no scope for the woman to show their potential and talent. They are subjugated, cabined and confined by the male members of the society (ISA) through different institutions of family, traditions, marriage house etc. (RSA) (Althusser, 1969)

He Vs She

The frequency of occurrence clearly suggests that these binaries have no comparison at all. "He" occurs 1402 times where "She" occurs 547 times. "He" occurs 3 times more than "she". It suggests that in society as well as in the narration, "she" has little space and scope to assert herself. The authority of male (ISA) is naturalized as an ideology in the society. It does not seem something abnormal or out of place when men assert their authority in the garb of different institutions. (RSA) (Fairclough, 2010; Wodak, 2010) 
"He" has specific identity which is created through his age, physique physical features, habits, achievements, status etc but woman has no such privilege. She does not enjoy a specific identity like man. She is just a facilitator for man in the daily routine of life.

"He" is an active energetic contributor on the business of life. "She" is just marrying, producing children, involved in fair and foul love-affairs. She has no achievements to eulogize nothing to be proud of only a tool in the hands of men.

\section{Results}

As the title of the novel suggests that the focus of the novel is woman. Stone woman is actually a statue of a woman near the palace of the narrator. The narrator belongs to the ruling class of Turkey but they lose the trust of the ruler at that time and have been banished from Istanbul to live in this palace which is located on a very scenic background. The main variable of our analysis of the novel becomes deprivation and oppression of women at the hands of men. For this purpose the nouns under study have been divided into two categories; the oppressed and the oppressors. The oppressed are the women and the oppressors are all the male characters.

The Pasha family is a conservative, traditional, ruling gamily in which women are not allowed to speak about their wishes, aims, and ambitions. The analysis of the noun "woman" shows that she has been qualified negatively most of the time, to be a woman is like a burden in that society as is admitted by one of the characters (Nilofer). The dominance of man over woman is explicit but this dominance is like a routine, it is not resisted or protested but it has been institutionalized (Fairclough, 2010; Wodak, 2010). Man acts as ISA and uses the institutions like family, marriage and traditions as RSA to naturalize his dominance and certain ideologies. (Althusser, 1969) The women of the Pasha family have no identity. They have no source to express their feelings and emotions. This is due to the strict structure of the family which works as RSA in the hands of man. In order to relieve themselves by expressing their pent up feelings, women of the Pasha family choose the statue of the stone woman. These women visit the statue of the stone woman solemnly and express their hidden truths and secrets before it. They treat the statue as their living partner, sharing and caring. This shows the cabined and caged life of the women. The men are so aloof from the women that they do not care about them. It bespeaks the low status of women in that society. There is the main character of Nilofer who marries against the wishes of her parents; she has illicit relationships with Selim (the son of the family barber). She is punished for her disobedience as she is banished from the family. It shows that women were deprived of their rights; they were not allowed to take the important decisions of their lives.

If we go on the other side of the divide i.e. the oppressors, we come to know that the male members of the Pasha family are arrogant, proud and have full authority over women. The verbs used with these nouns are action verbs. On the level of the sentence, they act as agents. There is a use of a lot of apostrophe with these nouns which indicates the sense of ownership. All this is in contrast with the female nouns that have been shown passive most of the time, they have no identity and are submissive. Mehmat Pasha is a morally weak and wicked person who exploits the women of the inferior classes but all his weakness is ignored because he is the male member of the family. All his actions are accepted as an ideology.

There is an interesting comparison between the personal pronouns "he" and "she". "he" has a very large frequency of occurrence as compared to "she". It shows the importance of the male members of the society. "he" has been shown active and agent whereas "she" has been shown passive and submissive. "he" has his own identity and achievements but "she" has none.

In short, the superiority of man over woman has been displayed on the lexical, syntactic and semantic level. The society is male dominant and women are deprived of their rights. The male chauvinism acts as an ideology very secretively and everything seems natural and normal. (Fairclough, 2010) The narrative does not show apparently that some ideology has been internalized. When we go through the patterns of the corpus and apply Gee(2011) tools for CDA, we come to know that the ideology of the dominance of man and deprivation and exploitation of woman has been at work in the narrative. Also, man has been using the institutions of family, marriage and traditions as RSA to subjugate the woman.(Althusser, 1969)

The Pasha family is representative of the Muslims of that time. The women of the most of the Muslim families have been mistreated in the same way. Their rights have been denied to them and they are living under the permanent threat of male chauvinism. This dominance of the male class and the deprivation of the female class is opaque, normal and is accepted by everyone. It is the nature of ideology that it remains embedded in the routine (Fairclough, 2010) and nothing seems out of way to us. Moreover, this ideology has been internalized and institutionalized through different institutions like marriage, family and traditions. The male members of the society act as ISA and use the above mentioned institutions as RSA to subjugate the female members of the 
society.

Despite the passage of centuries, the situation in the conservative societies has not changed much. The tools and institutions for subjugating women might have changed but the same opaque ideology of the narrative of Tariq Ali is still at work.

\section{References}

Ali, S. (n. d.) Journal of Culture, Society and Development, 3, 61-68. Retrieved from https://www.researchgate.net/.../282024980

Ali, T. (2000). The Stone Woman. London: Verso.

Ali, T. (2003). The clash of fundamentalisms: crusades, jihads and modernity. London: Verso.

Althusser. (1970). Overdetermination and Contradiction (pp. 87-128). In For Marx (Trans. By Ben Brewster). New York: Vintage Books.

Althusser. (1976). Essays in Self-Criticism. (Trans. By Grahame Lock). London: New Left Books.

Baker, P., Gabrielatos, C., \& Krzyżanowski, M. et al. (2008). A useful methodological synergy? Combining critical discourse analysis and corpus linguistics to examine discourses of refugees and asylum seekers in the UK press. Discourse and Society, 19(3), 273-306. https://doi.org/10.1177/0957926508088962

Biber, D. (1995). Variation across speech and writing. Cambridge: CUP.

Biber, D., Conrad, S., \& Reppen, R. (1998). Corpus linguistics: investigating language structure and use. Cambridge: Cambridge University Press. https://doi.org/10.1017/CBO9780511804489

Bondi, M. (2007). Keywords and emotions: A case study of the Bloody Sunday inquiry. In N. Fairclough, G. Cortese, \& P. Ardizzone (Eds.), Discourse and contemporary social change (pp. 407-432). Bern: Peter Lang.

Bourdieu, P. (1991). Language and Symbolic Power. Cambridge, MA: Harvard University Press.

Fairclough, N. (1995). Media Discourse. London: Arnold.

Fairclough, N. (1999). Democracy and the public sphere in critical research on discourse. In R. Wodak \& C. Ludwig (Eds.), Challenges in a changing world: issues in Critical Discourse Analysis (pp. 63-85). Vienna: Passagen Verlag.

Fairclough, N. (2000). Discourse, social theory and social research: the discourse of welfare reform. Journal of Sociolinguistics, 4(2), 163-195. https://doi.org/10.1111/1467-9481.00110

Fairclough, N. (2001). Language and power (2nd ed.). Harlow: Longman.

Gee, P. (2010). How to Do Discourse Analysis (2nd ed.). London: Routledge.

Groom, N. W. (2007). Phraseology and epistemology in humanities writing: a corpus-driven Study. PhD Thesis, University of Birmingham.

Halliday, M. A. K., \& Matthiessen, C. M. I. M. (2004). An introduction to functional grammar (3rd ed.). London: Arnold.

Hasan, W. (2014). European Scientific Journal, 10, 312-326. Retrieved from https://www.academia.edu

Heller, M. (2001). Discourse and Interaction. In D. Schiffrin, D. Tannen, \& H. E. Hamilton (Eds.), The Handbook of Discourse Analysis (pp. 250-264). Oxford: Blackwell.

Holmes, J. (2005). Power and Discourse at Work: Is Gender Relevant? In M. M. Lazar (Ed.), Feminist Critical Discourse Analysis: gender, power and ideology in discourse. Basingstoke: Palgrave Macmillan. https://doi.org/10.1057/9780230599901_2

Huntington, S. P. (1997). The clash of civilizations and the remaking of world order. Delhi: Penguin Books India.

Khosravinik, M. (2009). The representation of refugees, asylum seekers and immigrants in British newspapers during the Balkan conflict (1999) and the British general election (2005). Discourse and Society, 20(4), 477-498. https://doi.org/10.1057/9780230599901_2

Knight, D. (2009). A multi-modal corpus approach to the analysis of backchanneling behaviour. PhD Thesis, University of Nottingham.

Koller, V., \& Mautner, G. (2004). Computer Applications in Critical Discourse Analysis. In C. Coffin, A. Hewings, \& K. O'Halloran (Eds.), Applying English grammar: functional and corpus approaches (pp. 
216-228). London: Arnold.

Krishnamurthy, R. (1996). Ethnic, racial and tribal: The language of racism? In C. R. Caldas Coulthard \& M. Coulthard (Eds.), Texts and practices: readings in critical discourse analysis (pp. 129-149). London: Routledge.

Lazar, M. M. (2000). Gender, discourse and semiotics: The politics of parenthood representations. Discourse and Society, 11, 373-400. https://doi.org/10.1057/9780230599901_2

Leech, G., Rayson, P., \& Wilson, A. (2001). Word Frequencies in Written and Spoken English: Based on the British National Corpus. Harlow: Pearson Education Ltd.

Martin, J. R. (2004). Mourning: How we get aligned. Discourse and Society, 15(2-3), 321-344. https://doi.org/10.1177/0957926504041022

Martin, J. R., \& White, P. R. R. (2005). The language of evaluation. Basingstoke: Palgrave Macmillan. https://doi.org/10.1057/9780230511910

Mason, O. (2000). Parameters of Collocation: The word in the centre of gravity. In J. M. Kirk (Ed.), Corpora Galore: Analyses and Techniques in Describing English (pp. 276-280). Papers from the 19th International Conference on English Language Research on Computerised Corpora. Amsterdam: Rodopi.

Meyer, C. F. (2002). English corpus linguistics: an introduction. Cambridge: Cambridge University Press. https://doi.org/10.1057/9780230511910

Meyer, M. (2001). Between Theory, Method and Politics: positioning of the approaches to CDA. In R. Wodak \& M. Meyer (Eds.), Methods of critical discourse analysis (pp. 14-31). London: Sage.

Myers, G. (2008). Analyzing Interaction in Broadcast Debates. In R. Wodak \& M. Krzyżanowski (Eds.), Qualitative discourse analysis in the social sciences (pp. 121-144). Basingstoke: Palgrave Macmillan. https://doi.org/10.1057/9780230511910

O’Halloran, K., \& Coffin, C. (2004). Checking Overinterpretation and Underinterpretation: Help from Corpora in Critical Linguistics. In C. Coffin, A. Hewings, \& K. O’Halloran (Eds.), Applying English grammar: functional and corpus approaches (pp. 275-297). London: Arnold.

Oakes, M. P. (1998). Statistics for corpus linguistics. Edinburgh: Edinburgh University Press.

Orpin, D. (2005). Corpus Linguistics and Critical Discourse Analysis: Examining the ideology of sleaze. International Journal of Corpus Linguistics, 10(1). https://doi.org/10.1075/ijcl.10.1.03orp

Patton, M. Q. (2002). Qualitative Research and Evaluation Methods (3rd ed.). Thousand Oaks, California: Sage Publications.

Pollack, A. (2008). Analyzing TV Documentaries. In R. Wodak \& M. Krzyżanowski (Eds.), Qualitative discourse analysis in the social sciences (pp. 77-95). Basingstoke: Palgrave Macmillan. https://doi.org/10.1007/978-1-137-04798-4_4

Ramazanğolu, C., \& Holland, J. (2002). Feminist Methodology: Challenges and Choices. London: SAGE Publications Ltd. https://doi.org/10.4135/9781849209144

Reisigl, M. (2008).Analysing Political Rhetoric. In R. Wodak \& M. Krzyżanowski (Eds.), Qualitative discourse analysis in the social sciences (pp. 96-120). Basingstoke: Palgrave Macmillan. https://doi.org/10.1007/978-1-137-04798-4_5

Reisigl, M., \& Wodak, R. (2009). The Discourse-Historical Approach (DHA). In R. Wodak \& M. Meyer (Eds.), Methods of critical discourse analysis (2nd ed., pp. 87-121). London: SAGE.

Schäffner, C. (1997). Editorial: Political Speeches and Discourse Analysis. In C. Schäffner (Ed.), Analysing political speeches (pp. 1-4). Clevedon: Multilingual Matters.

Scott, M. (1997). PC Analysis of Key Words-And Key Key Words. System, 25(2), $233-245$. https://doi.org/10.1016/S0346-251X(97)00011-0

Sinclair, J. M. (1991). Corpus, concordance, collocation. Oxford: Oxford University Press.

Sinclair, J. M. (2004). Trust the text: language, corpus and discourse. London: Routledge.

Sinclair, J. M., Jones, S., \& Daley, R. et al. (2004). English collocation studies: the OSTI report. London: Continuum.

Stubbs, M. (1996). Text and Corpus Analysis. Oxford: Blackwell. 
Stubbs, M. (2001). Computer-Assisted Text and Corpus Analysis. In D. Schiffrin, D. Tannen, \& W. Teubert (2003). Writing, Hermeneutics and Corpus Linguistics. In Logos and Language, IV(2), 1-17.

Stubbs, M. (2008). The discourse and the concept of (intellectual) property. University of Birmingham Department of English Staff-Student Seminars, Lecture given at the University of Birmingham, 18 January 2008.

Tognini Bonelli, E. (2001). Corpus linguistics at work. Amsterdam: John Benjamins. https://doi.org/10.1075/scl.6

Van Dijk, T. A. (1996). Discourse, power and access. In C. R. Caldas-Coulthard \& M. Coulthard (Eds.), Texts and practices: readings in critical discourse analysis (pp. 84-106). London: Routledge.

Van Dijk, T. A. (2001). Critical Discourse Analysis. In D. Schiffrin, D. Tannen, \& H. E. Hamilton (Eds.), The Handbook of Discourse Analysis (pp. 352-371). Oxford: Blackwell.

Van Leeuwen, T. (2009). Critical Discourse Analysis. In J. Renkema (Ed.), Discourse, of course: an overview of research in discourse studies (pp. 277-292). Amsterdam; Philadelphia: John Benjamins Pub. Co. https://doi.org/10.1075/z.148.27lee

Widdowson, H. G. (2000). On the limitations of linguistics applied. Applied Linguistics, 21(1), 3-25. https://doi.org/10.1093/applin/21.1.3

Wilson, J. (2001). Political Discourse. In D. Schiffrin, D. Tannen, \& H. E. Hamilton (Eds.), The Handbook of Discourse Analysis (pp. 398-415). Oxford: Blackwell.

Wodak, R. (2009). The semiotics of racism: A Critical Discourse-Historical Analysis. In J. Renkema (Ed.), Discourse, of course: an overview of research in discourse studies (pp. 311-326). Amsterdam; Philadelphia: John Benjamins Pub. Co. https://doi.org/10.1075/z.148.29wod

Wodak, R., \& Meyer, M. (2009). Critical Discourse Analysis: history, agenda, theory and methodology. In R. Wodak \& M. Meyer (Eds.), Methods of critical discourse analysis (2nd ed., pp. 1-33). London: SAGE.

Wodak, R., de Cillia, R., Reisigh, M. et al. (2009). The Discursive Construction of National Identity. Edinburgh: Edinburgh University Press.

\section{Copyrights}

Copyright for this article is retained by the author(s), with first publication rights granted to the journal.

This is an open-access article distributed under the terms and conditions of the Creative Commons Attribution license (http://creativecommons.org/licenses/by/4.0/). 